\title{
Peter F. Hjorts innsats for palliativ medisin
}

\author{
Det som på 1980-tallet var en bevegelse preget av idealisme og frivillighet, er i dag et anerkjent klinisk \\ og akademisk fag.
}

Peter F. Hjort (1924-2011) står i en særstilling i norsk medisin. Etter sin død 1.1.2011 ble han hedret med hele fire nekrologer i Tidsskriftet (1-4) og omtalt i redaktørens leder (5), der hans bredde og mangfoldighet beskrives godt. Det som ikke er omtalt, er hans bidrag til palliativ medisin. Hjort var den første legen i Norge som med tyngde engasjerte seg på dette fagområdet.

\section{Utfordringer som ung lege}

Allerede som fersk ung lege på Rikshospitalets hematologiske avdeling i begynnelsen av 1950-årene fikk han erfaring med behandling og omsorg av alvorlig syke og døende. Tilnærmingen var den gang preget av:

- Vi skulle kjempe til siste slutt

- Vi skulle snakke ærlig til de pårørende, men ikke med pasienten

- Visitten gikk forbi de døende, sykepleierne tok seg av dem

- Vi var engstelige for å gi for mye morfin (6)

I 1953 fikk han ansvar for behandlingen av en av norsk medisins høvdinger, Johan Holst (1892-1953), som hadde fått leukemi. Holst, som var Hjorts onkel, var sammen med Carl Semb (1895-1971) grunnleggeren av norsk thoraxkirurgi og medvirkende til at vi fikk de første anestesilegene i Norge (7). Holst ruvet i landskapet på mange måter. Det var derfor med stor ærbødighet og respekt Hjort nærmet seg pasienten. I et intervju jeg hadde med ham i 2009 beskrev Hjort hva som skjedde:

Jeg søkte etter støtte på biblioteket og leste den eneste boken jeg kunne finne. Forsiktig spurte jeg: «Vil du ha morfin?» Den gamle kjempen svarte på engelsk: «You are the doctor»"

Forsiktig ga han Holst den morfinen han trengte for å få god smertelindring samtidig som han behandlet de andre symptomene.

\section{Nye prinsipper}

Denne hendelsen tok Peter Hjort med seg. Sammen med andre tilsvarende opplevelser kom dette til å prege ham og hans medisinske praksis i alle år. Da han senere ble sjef på Rikshospitalets avdeling for blodsykdommer, tok han i bruk helt nye prinsipper som ivaretok pasientene og deres pårørende på en langt bedre og annerledes måte, bygd på tre hovedregler:

- Legen skal kommunisere med både pasient og pårørende, og de skal informeres sammen

- Den nærmeste pårørende skal få en seng ved siden av pasienten i den siste terminale fasen
- All livsforlengende behandling ble da avsluttet til fordel for lindrende behandling

Hjort hentet her inspirasjonen fra hospicebevegelsen i England og fra Cisely Saunders' (1918-2005) publikasjoner om behandling, pleie og omsorg for alvorlig syke og døende. I 1967 sørget han for å få publisert en artikkel av Saunders i Tidsskriftet (7). Selv skrev han en anmeldelse (8) av hennes bok Care of the dying (9) og en meget god lederartikkel, med tittelen Om døden (10), som kan leses med stort utbytte i dag, 44 år etter.

\section{Fra mikro til makro}

I 1969 reiste Peter Hjort til Tromsø for å være med på å bygge opp det nye universitet der. Han ble den første rektor der, men valgte i 1973 å dra tilbake til Oslo etter en uenighet med studentene (4). Om tiden i Tromsø sa han til meg: «Jeg forandret meg. Jeg beveget meg fra mikro til makro». Fra å være spesialist i blodsykdommer, hvor mikroskopet var et viktig redskap, ble han mer opptatt av samfunnsmedisinske problemstillinger. I 1974 reiste han sammen med Ragna Følling Elgjo (1931-) og Christian Borchgrevink (1924-) på et besøk på St. Christophers Hospice i London, der de møtte Cisley Saunders, som hadde inspirert Hjort 15 år tidligere.

Etter et nytt og lengre studieopphold i England året etter søkte Hjort om midler til å få opprettet et forskningssenter. Dette initiativet ble til NAVFs gruppe for helsetjenesteforskning etter at Norges allmennvitenskapelige forskningsråd hadde bevilget midler for fem års drift. Under oppholdet i England ble han kjent med forskningen til Ann Cartwright (1925-), som hadde ledet et prosjekt om terminalomsorg, og som hadde gitt ut boken Life before death (11). Et av de første områdene Gruppe for helsetjenesteforskning engasjerte seg i, var situasjonen for de alvorlig syke og døende. Liv Wergeland Sørbye (1947-) ble ansatt som vitenskapelig assistent. Parallelt fortsatte Hjort med sin skriveaktivitet og publiserte blant annet en artikkel i Medisinsk Årbok i 1978 med tittelen «Den håpløst syke og døende pasient» (12).

\section{Engasjement livet ut}

Alt dette skjedde før det som kan regnes som starten på faget palliativ medisin i Norge. Etter hvert engasjerte Den norske kreftforening seg, vi fikk Omsorgsrådet, og utover i 1980-årene kom det andre aktører inn på banen, blant annet i Bergen og
Trondheim. Hjort var - sammen med bl.a. Brita Paus (1917-98) og Bernhard Paus (1910-99) i Fransiskushjelpen - en katalysator for denne prosessen.

Hjort fulgte nøye med på det som skjedde. Ikke minst var han sterkt engasjert i de store etiske utfordringene rundt livsforlengende behandling, feilbehandling og eutanasi. Dette ga seg også uttrykk i det sterke engasjement og den dype kjærlighet han viste sin kone ved å behandle og pleie henne i deres hjem under hennes sykdom og død. Peter F. Hjort er kanskje den viktigste premissleverandøren for utviklingen av det som på 1980-tallet var en bevegelse preget av idealisme og frivillighet, og som $i$ dag er blitt et anerkjent klinisk og akademisk fag.

\section{Kjell Erik Strømskag \\ kjeer-st@online.no \\ Akuttavdelingen \\ Molde sjukehus}

Kjell Erik Strømskag (f. 1952) er spesialist $i$ anestesi og overlege ved Akuttavdelingen. Oppgitte interessekonflikter: Forfatteren har mottatt stipend fra Norsk Faglitterær Forfatter-og Oversetterforening.

\footnotetext{
Litteratur

1. Bjørndal A. Peter F. Hjort. Tidsskr Nor Legeforen 2011; 3: 316-7.

2. Ranhoff AH, Sletvold O, Wyller TB et al. Peter F Hjort. Tidsskr Nor Legeforen 2011; 3: 317.

3. Janbu T, Riise G. Peter F. Hjort. Tidsskr Nor Legeforen 2011; 3: 318.

4. Aarbakke J, Nordøy A. Peter F. Hjort. Tidsskr Nor Legeforen 2011; 3: 318.

5. Haug C. Dette må vi gjøre noe med. Tidsskr Nor Legeforen 2011; 2: 107

6. Strømskag KE. Et fag på søyler. Anestesiens historie i Norge. Oslo: Tano-Aschehoug, 1999

7. Saunders C. The last stages of life. Tidsskr Nor Lægeforen 1967; 87: 248-52.

8. Hjort PF. Bokanmeldelse. Saunders C. Care of the dying. Tidsskr Nor Lægeforen 1967; 87: 252

9. Sauders C. Care of the dying. London: Nursing Outlook, 1967.

10. Hjort PF. Om døden. Tidsskr Nor Lægeforen 1967; 87: $267-8$.

11. Cartwright A, Hockey L, Anderson JL. Life before death. London: Routledge \& Kegan Paul, 1973.

12. Hjort PF. Den håpløst syke og døende pasient. I: Vejlsgaard R, red. Medisinsk Årbok. Oslo: Olaf Norlis Bokhandel, 1978; 114-23.
}

Mottatt 9.6. 2011, første revisjon innsendt 11.8. 2011, godkjent 25.8. 2011. Medisinsk redaktør Petter Gjersvik. 